\title{
Geology and geochemistry of the VOLPA seafloor massive sulfide deposit, Niua volcano, Tonga
}

T. MOUM ${ }^{1}$, M.O.ANDERSON ${ }^{1}$, J. JAMIESON ${ }^{2}$, R. PARKINSON $^{3}$, E. AUSTIN ${ }^{3}$

${ }^{1}$ Department of Earth Sciences, University of Toronto, Canada, talia.moum@utoronto.ca

${ }^{2}$ Department of Earth Sciences, Memorial University of Newfoundland.

${ }^{3} \mathrm{SM} 2$ - Seabed Minerals, St. Helier, Jersey

More than 500 hydrothermal vent sites have been found in various tectonic settings, ranging from mid-ocean ridges, to volcanic arcs and back-arc basins. Sites that are hightemperature and contain significant accumulations of metals $(\mathrm{Cu}, \mathrm{Zn}, \mathrm{Pb})$ are referred to as seafloor massive sulfide (SMS) deposits. We explore the geology and geochemistry of the VOLPA SMS deposit on Niua Volcano, northern Tonga arc. Niua is a rectangular complex that formed within a graben feature, where arc volcanism and back-arc rifting processes coincide. VOLPA chimneys are hosted along the rim of a large crater feature, with fewer chimneys on the crater floor associated with hydrothermal mounds. The terrain is mainly smooth with small areas of hummocky lava flows. Geological and structural mapping is integrated with petrological and geochemical studies of ore assemblages and fresh volcanic rocks, including major- and trace-element geochemistry, S-isotope systematics, and ${ }^{226} \mathrm{Ra} / \mathrm{Ba}$ dating of hydrothermal barite. VOLPA is notable for the abundance of barite-rich diffuse (beehive) chimneys with 636 wt. $\% \mathrm{Ba}$. This study is adding to a growing work on the diversity of SMS deposits on the seafloor and specifically along the Tonga-Kermadec arc. 